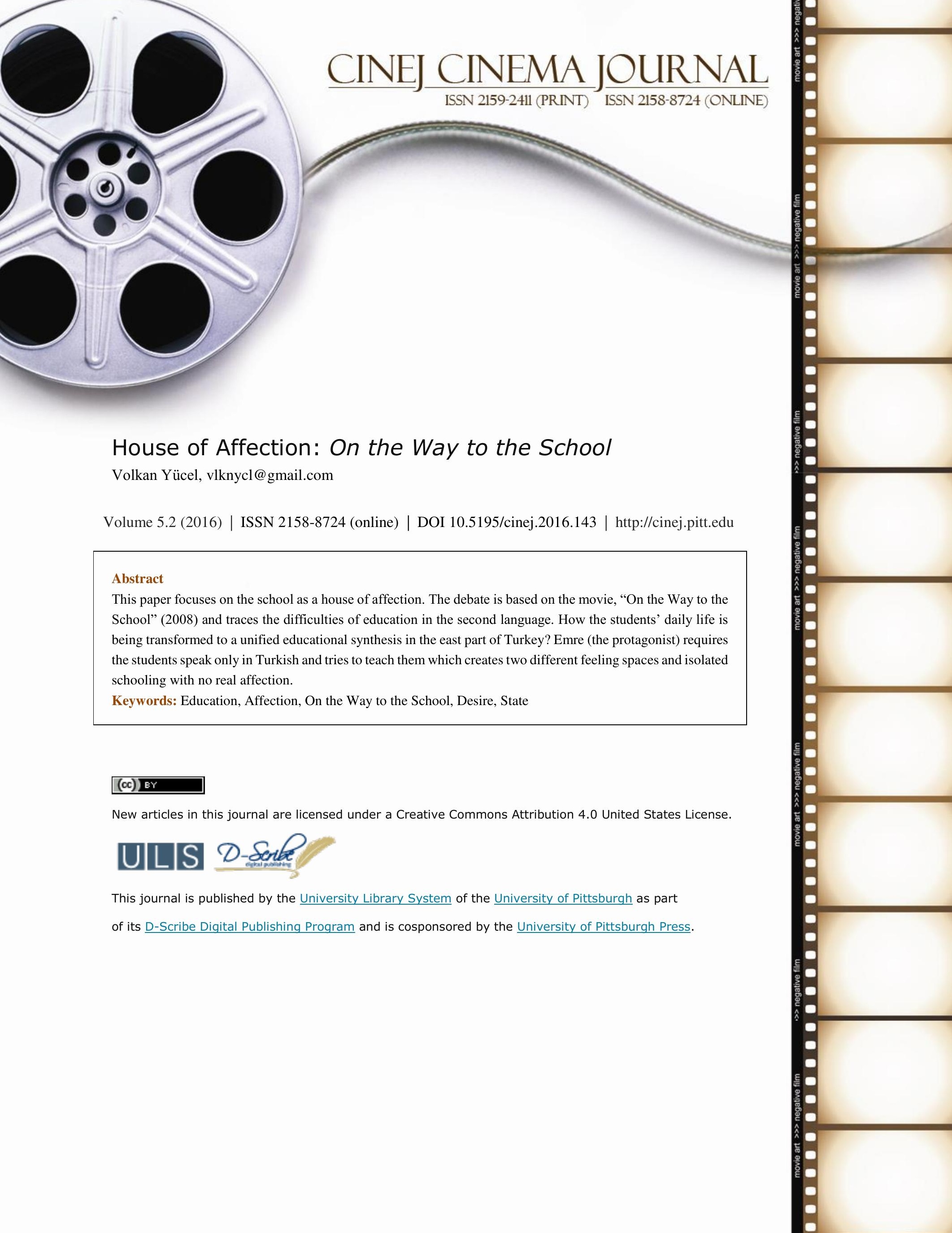




\section{House of Affection: On the Way to the School}

\section{Volkan Yücel}

\section{Introduction}

One of the most fundamental environment where the affects are embodied and formed is the school space. Little children go to this house of affection to act in a manner. A teacher, as a second father or the first resemble of the big other is waiting to realize the symbolic order over the students.

Education provides self-identification and self-recognition mostly achieved by first language acquisition as a cultural system. There are 8,000 spoken languages in the world, however, only a few hundreds of them are in use. Several words in a language different from the mother tongue or some affects aimed by them cannot create an authentic personality. Language is the first personal freedom in the symbolic order. Gains in mother tongue experience are unique when improving personal cognition in the childhood.

The school is the first space/place to make infants sentimentally educated (Figure 1). Friends, ideas about life and earth, songs and sharing through games and education make children to create and explore themselves.

There is an ongoing language conflict in Turkey where is a wide range of cultural, racial, religious and linguistic diversity. Using only Turkish in formal education out of minority schools is a severe education problem. The education system tries to restrain, especially Kurdish students from continuing their mother tongue as an assimilationist policy.

This condition has in a given region in Turkey, where mostly Kurdish children are. Even though there are no specific penalties for speaking Kurdish in the schools, teachers require Kurdish students speak only in Turkish for lessons. They live in different affective spaces. 
Learning Turkish becomes compulsory to be accepted by the society, to be socially confident or to find a job. One of the best films that examines this situation is On the Way to the School (Özgür Doğan and Orhan Eskiköy, 2008). ${ }^{1}$ The documentary points out a vital communication problem and an educational inefficacy in general which fails to give a sentimental or an affective promise.

On the Way to the School (Du Ziman $\hat{u}$ Yek Bahol, 2008) $)^{2}$ is a documentary about a Turkish teacher who is alone in a village as an authority of the state, and about his interaction with the Kurdish children who have to learn Turkish.

The film shows the one school year period between September 2007 and June 2008. The teacher from Denizli, the west of Turkey, is appointed for the first time to teach in an elementary school in Siverek, the east of Turkey. The Teacher Emre is Turkish and the people in the Siverek are Kurdish. The life in the village is grueling for Emre, who comes from a big city. There is no water, no social life and the electricity comes and goes.

Emre rarely speaks with his family since he cannot charge the phone. Most of the children can speak only Kurdish and they don't understand the teacher. The most important problem is being lost in communication. Emre changes the curriculum and decides to teach only Turkish language. They begin to understand each other mutually and slowly. In this period, we witness the difficulties and blocks which Teacher Emre and students have.

\section{Different Spaces of Affect in the Movie}

The being and the sensation behind it can be defined by many approaches. L. Wittgenstein says, "The limits of my language mean the limits of my world.". ${ }^{3}$ Subjectivity and human character develop around these limits and definitions. For instance; being can be defined 
as thought (Epicure), conatus (Spinoza), or the desire (Lacan). Further to that, there are sensational concepts like libido (Freud), will power (Nietzsche) or affect (Spinoza) by some philosophers.

Philosophy sometimes ignores the human feelings, smells, emotions and sentimental subjectivity when it tries to define human condition. Yet it is the interaction and reflective inner actions between humans that makes them what they are to be. And the first step in life based on imitation is educational process. The school space is not only a formal source of education, but also an in formal source of actions taking place between students as serving as viral learning.

When considered from this point of view, interaction space of teacher and interaction space of students in the movie don't match. Emre is a well-intentioned person, but an ineligible teacher. He denies speaking Kurdish in class in order that students can learn Turkish. However he speaks with an Aegean 'accent' and he fails in 'formal Turkish accent' in this respect.

He cannot teach even basic words such as bird or flower. After that he thinks that he does everything in vain, he tries to speak with students' parents. But they also don't understand Turkish. Only some parents can speak Turkish a little. Emre feels ineffective and helpless again in this cultural space. And he feels alienated. Emre is imprisoned in his own affectional space (Figure 2). Also, he does not create an affect over student through formal education.

Language is the most important problem of not creating affect over students. There is a sealed identity in the movie which teacher tries to transfer beyond the language. These units can create an influence if they are transferred via language, but it does not constitute a symbolic interaction: "The body has a grammar of its own that cannot be fully captured in language". 4 


\begin{tabular}{|l|l|}
\hline Emre's Affect Space & Kurdish Student's Affect Space \\
\hline Turkish language & Kurdish language \\
\hline Turkish flag & Kurdish conventions \\
\hline Turkish school & Local conditions \\
\hline Turkish education system & Kurdish Culture \\
\hline Turkish culture & Authenticity \\
\cline { 1 - 1 } Turkish discourse and oath (Happy is he & \\
\cline { 1 - 1 } Turkish educational material & \\
\cline { 1 - 2 } State & \\
\cline { 1 - 1 } Legitimate official & \\
\hline
\end{tabular}

The most important barriers of affect spaces as shown in the above table are language, culture and identity. Children are forced to feel and experience affection in another language, but this is not possible. Politic education and training care transmission of values related to Turkish identity, but students aren't aware of what they learn. For this reason, character depth does not arise in the film, student are like no-name infants.

Local and political problems don't examine completely and the things told in the movie remain around a single event. Even though the language problem seems a pedagogical one, the movie is only about an event of non-communication itself. The fiction repeats the same event in order to pass this split of affect to us. This might be an intentional tool to make the audience feel blocked.

An affect is a nonconscious experience of creative intensity; it is a moment of unstructured potential. ${ }^{5}$ However, the school excludes the students from itself, thereby it externalizes the students' language in the beginning. 


\section{Kurdish Alienation}

In the east part of Turkey, educational conditions are inadequate because of economic underdevelopment. The majority of locals are Kurdish and the worst symbolic condition in the area is the language of education. According to policy of Turkish Ministry of Education, all lectures in the public schools should be given in Turkish. This is an old law like other Republic practices by M. K. Atatürk:

"Throughout the years of Republicanism, many people were brought up to be Turks in republican institutions, whether their ancestors be Abkhazian Muslim immigrants from Georgia, Slavic converts to Islam from Serbia, Armenianspeaking Muslims of the Hemşin region, or Arabs, Kurds, Lazes, Circassians, or other, Turkishness was internalized and adopted to varying extents and in various fashions. Some people had an easier time in assuming Turkishness as an identity than others. Some were willing to assimilate or to assume this identity, while others were not. This was less problematic for Circassians and Albanians, for example, than it has been for Kurds; easier for the Muslim-born and difficult for the willing Jew."

This code that supports the one-nation ideology seems failed in the Kurdish region. One of the most affective moments of the documentary is a dialogue between Emre and one of the locals. A local tells his experience of a job application resulted in a melancholy of identiy. ${ }^{7} \mathrm{He}$ wrote Turkish as his second language on the application form and the contact person cynically said that Kurdish is not a language.

There is no country in the world which accepts the Kurdish state identity. For this reason, a formal Kurdish identity is not legitimate and approved. This status sticks them and haunts repeatedly in their whole lives. Kurds are like a shadow in wherever they live. In Iraq, they are to be Iraqi, in İran, they are to be İranian and in Turkey, they are to be Turkish. Their cultural memory on the region seems legitimately empty: 
"Not only does space sediment collective history, but it also crafts personal experience by investing the urban land-scape with intense subjective meanings that endow the past with a visible immediacy, blending time and personal experience into a collective history through the mechanism of localized memory. In so doing this collective history does not function as a nostalgic narrative of times gone by; rather it projects itself into the future by acting as a mythical chart to explain and legitimize action in the present. The future is read in the marks of the past through the memory of what people were fighting for." $"$

There are many screams like this in the Kurdish history. These screams are reflected by music, mostly in the art. Kurds are very successful in the arts (mostly in music) although they don't have a distinct literature or cinema from the countries where they live (Mem $\hat{u}$ Zin is an exception). For example; there are music groups like Kamkars or Kardeş Türküler and individual singers like Ciwan Haco, Şivan Perwer and Ahmet Kaya. Particularly Ahmet Kaya is a mixed example. His Turkish songs birth various affections in many Turks despite of the fact that they are written in the second language. As a result of this success, Kurdish songs were transferred to Turkish music by TRT's singers.

Kurdish was prohibited during the 80s. In response to this, Kurds have organized in Europe through communities, parliaments and clubs and tried to conserve their own culture. Because of these reasons we can speak of Kurdish alienation and a mix culture shaped by their migrations.

\section{Desire in the House of Affection}

Kurds are not only deprived from affect space as homeland but also educational affect space. Kurdish children have difficulty in passing imaginary or symbolic order after splitting from the real. Students encounter a false symbolic space instead of the symbolic order (house of affect) 
when they go to the school by leaving from home of mother and mother tongue (the real). As Lacan argues that the constitution of self is bound up with the world of images and representations $^{9}$; thus the self has no essential qualities, since it is not born, but made.

Students are not introduced to their own language. Being a subject requires a split from the mother. The authority (Emre) of this false symbolic order and space blocks the students' split from their mother, since he is a false father. Emre cannot put them in the symbolic order. He is in there as an authority of the symbolic order, but he cannot function. Thus, they experience their first alienation instead of gaining an identity in the educational space. The students are real, but they cannot pass to space of the imaginary or the symbolic.

While the Turkish symbolic order in the school (Turkish educational environment) is a place objectifying Emre, it is subjectifying the students. However the house of affection could be ryzomatic itself beyond the Lacanian analysis (Figure 3). To the Lacanian perspective, house of desires in the movie is a house of deficiencies because the father cannot fulfill his Lacanian function.

The school cannot need to be an Oedipal palace (place) for the Deleuzeian aspect. We have knowledge of our affections through the ideas we have, sensations or perceptions. ${ }^{10}$ Especially the primary school should be a ryzomatic network in where the students' affective interactions function. If the school cannot establish a symbolic order, it cannot stay as a house of desires (up to Lacan) and house of education envelops the affect instead unfolding it (up to Deleuze). 


\section{Conclusion}

A documentary can give a lot of virtual knowledge than any fiction. On the Way to the School uses this potential to show how the affection happens in Turkish total education. According to J. Jervis, movies are an important source of subjectivity as an extension of the reality:

"We experience sensations, just as we are subjected with them through the media. 'Sensational subjects' are produced and reproduced in modernity both as the agent having the experience and as the topic experienced, both subjective and objective dimensions of the modern spectacle." 11

A documentary is usually about thigs that cannot be represented. In On the Way to the School, there is an ongoing frustration of the protagonist, since the aim is never achieved. All the movie is a about single event that fails to be realized. A house of affection is supposed to be a desires of house. The school in the movie is not a place to be desired but a quiet place for years.

Emre is cross-outed by his students/subjects. He is the first spook figure in the students' life. And Kurdish children are supposed to encounter with many kinds of this figure during their life. Many teachers like Emre, as being the first formal authority, minimize students' own mother tongue, postponed their affection process and put a pedagogical image in their bodies and minds. Their house of affection is not ease and somewhat alienated.

\section{BIBLIOGRAPHY}

Aretxaga, B. (1997). Shattering Silence: Women, Nationalism, and Political Subjectivity in Northern Ireland. New Jersey: Princeton University.

Cheng, A. A. (2000). The Melancholy of Race. New York: Oxford University.

Deleuze, G. (1997). Essays: Critical and Clinical. Minneapolis: University of Minnesota. 
Jervis, J. (2015). Sensational Subjects: The Dramatization of Experience in the Modern World. London: Bloomsbury.

Lacan, J. (2014). Baba-nın Adlart. Istanbul: Monokl.

Massumi, M. (2002). Parables for the Virtual: Movement, Affect, Sensation. Durham: Duke University.

Moore, H. (2002). Gendered Persons: Dialogues between Anthropology and Psychoanalysis. In S. Heald and A. Deluz (Ed.), Anthropology and Psychoanalysis (pp.131-148). New York: Routledge.

Navaro-Yashin, Y. (2002). Faces of the State. New Jersey: Princeton University.

Wittgenstein, L. (2014). Tractatus Logico-Philosophicus. London: Routledge.

\section{FIGURE LIST}

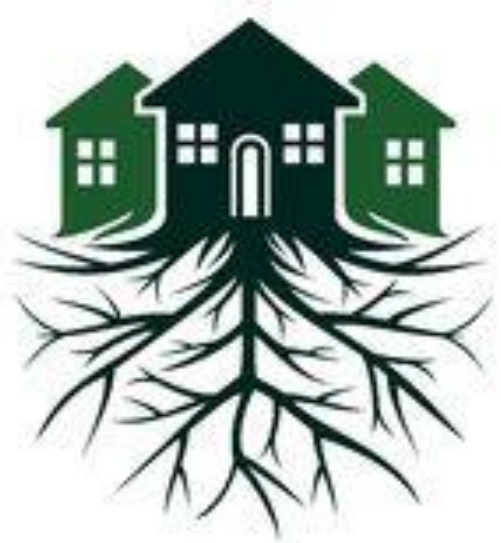

Figure 1 The house of affection: The school 


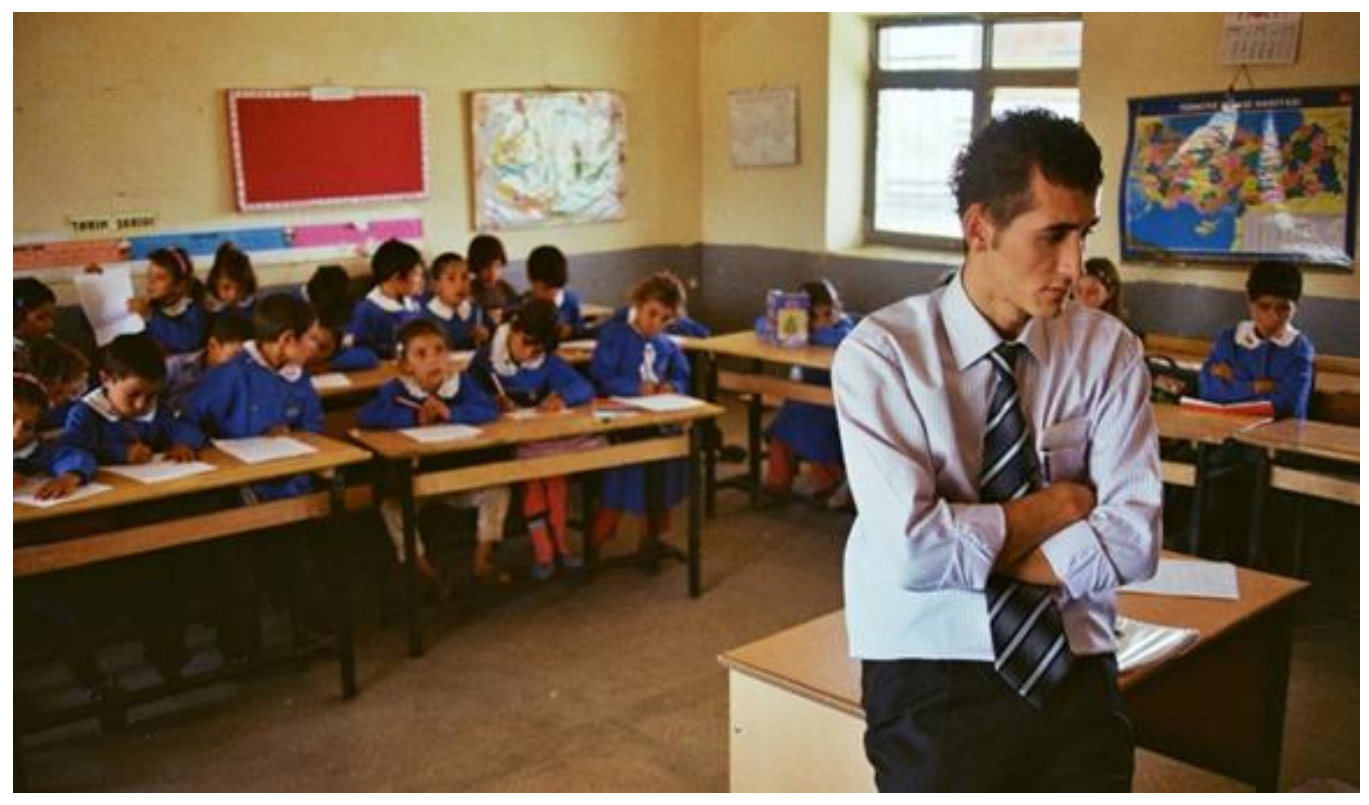

Figure 2 Emre is in his own affect space

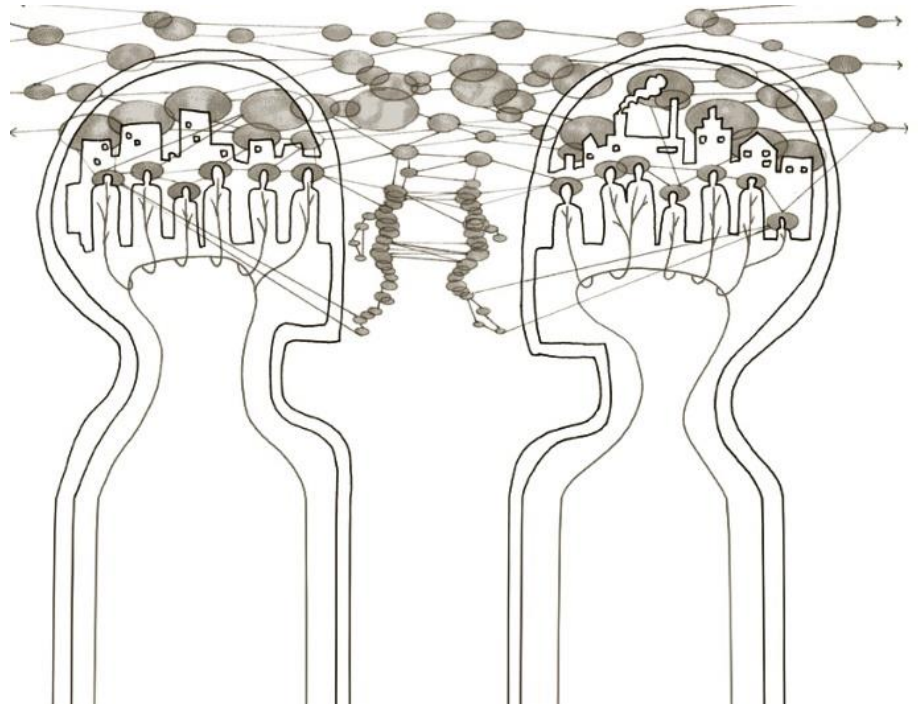

Figure 3 Space of ryzomatic affection in education 


\section{ENDNOTES}

${ }^{1}$ Racial melancholia plays itself out not only in national formation but also in one of its expressions: the formation of canonical literature (Cheng, 2000, p.12).

Cheng, A. A. The Melancholy of Race, New York, Oxford University, 2000.

${ }^{2}$ (On the Way to the School, Iki Dil Bir Bavul 2008).

${ }^{3}$ Wittgenstein, L. Tractatus Logico-Philosophicus. London, Routledge, 2014, p. 30.

${ }^{4}$ Massumi, M. Parables for the Virtual: Movement, Affect, Sensation, Durham, Duke University, 2002, p. $30)$.

5 Ibid, p. 39.

${ }^{6}$ Navaro-Yashin, Y. Faces of the State, New Jersey, Princeton University, 2002, p. 49.

${ }^{7}$ Aretxaga, B. Shattering Silence: Women, Nationalism, and Political Subjectivity in Northern Ireland, New Jersey, Princeton University, 1997, pp. 37-29.

${ }^{8}$ Ibid, p. 38.

${ }^{9}$ Moore, H. "Gendered Persons: Dialogues between Anthropology and Psychoanalysis", In S. Heald and A. Deluz (Ed.), Anthropology and Psychoanalysis (pp. 131-148), New York, Routledge Moore, 2002, p. 143.

${ }^{10}$ Deleuze, G. Essays: Critical and Clinical, Minneapolis: University of Minnesota, 1997, p. 139.

${ }^{11}$ Jervis, J. (2015). Sensational Subjects: The Dramatization of Experience in the Modern World, London, Bloomsbury, 2015, p. 2. 